\title{
Regular exercise modulates obesity factors and body composition in sturdy men
}

\author{
II-Gyu Ko', Pil-Byung Choi ${ }^{2 * *}$ \\ 'Department of Physiology, College of Medicine, Kyung Hee University, Seoul, Korea \\ ${ }^{2}$ Department of Leisure Sports \& Recreation, Human Development, Yeonsung University, Anyang, Korea
}

The purpose of this study was to find the change and correlation between obesity factors and body composition according to regular exercise. Thirty-six sturdy men at twenty years old in ' $K$ ' university students were participated in this study. The subjects were randomly divided into two groups ( $n=18$ in each group): control group and regular exercise group. Exercise program composed of three programs: warm-up (10 $\mathrm{min})$, work-out (30-60 min), cool-down (10 min), and categorized by five days per week for eight weeks. Aerobic exercise using a treadmill at $60 \%$ of heart rate reserve was performed, and weight training was composed of nine different exercises for the large muscles. Before the performing regular exercise, there was no significant difference between control and regular exercise groups. In the present results, 8 weeks regular exercise significantly decreased leptin, weight, fat mass, $\%$ fat, waist to hip ratio (WHR), and body mass index (BMI) more than compared to before performing regular exercise, whereas significantly enhanced lean mass more than compared to before performing regular exercise. Furthermore, regular exercise group reduced leptin, weight, fat mass, \% fat, WHR, and BMI compared to control group in the post test. In the correlation of obesity-related factors and body composition, tumor necrosis factor- $\alpha$ (TNF- $\alpha$ ) showed correlation with weight, lean mass, and fat mass after performing regular exercise. Here in this study, we suggest that regular exercise is a valuable tool for the improvement of health in the sturdy men, because regular exercise suppresses body fat and obesity-related factors.

Keywords: Regular exercise, Leptin, Tumor necrosis factor- $\alpha$, Interleukin-6, Body composition

\section{INTRODUCTION}

Obesity is defined as a state of excess accumulation of adipose in adipocyte, as imbalance of adipose synthesis and degradation phenomena in adipose tissue cells (Kim et al., 2002). In the past, adipose tissue has been synthesized and storage by triglyceride for necessary supplies to other tissues and organs function only in a passive energy reservoir (Ko, 2007). However, to maintain the homeostasis of the energy of body that became known as adipose tissue (Houmard et al., 2000). It has been clearly demonstrated that adipose tissue are able to generate and to secrete several inflammation associated with appetite, such as leptin, tumor necrosis factor- $\alpha$ (TNF- $\alpha$ ), and interleukin-6 (IL-6) (Ziccardi et al., 2002).

Leptin, anti-obesity hormone to suppress appetite, is affected by the concentration of adipose tissue cells in adipocyte that elevated leptin concentration in sufficient nutrient intake when high levels of leptin signal is suppress appetite, the brain as opposed to judge from the low level of leptin signal is need to provide adipose (Ahima and Flier, 2000). But excessive nutrient intake and physical inactivity, the accumulation of fat due to the continuous increase of leptin resistance, reduce susceptibility to diet control ability to be lost. Thus, the system has already been an accumulation of many fat, despite makes hunger and overeating will eventually lead to obesity (Enriori et al., 2006). However, leptin is directly proportional to the amount of adipose tissue, reduced by reducing body fat with loss weight (Sartorio et al., 2003; Thomson et al., 2009). Kraemer et al. (2002) reported plasma leptin concentrations declined by $53 \%$ after loss weight of $10 \%$. Silha et al. (2003) measured leptin concentrations in reducing body 17 men and obese body 34 men. These results showed that leptin concentra-
${ }^{*}$ Corresponding author: Pil-Byung Choi

Department of Leisure Sports \& Recreation, Human Development, Yeonsung University, 37-34 Yangwha-ro, Manan-gu, Anyang 430-749, Korea

Tel: +82-31-441-1139, Fax: +82-31-442-4400, E-mail: pbchoi@yeonsung.ac.kr Received: March 25, 2013/ Revised: April 12, 2013/ Accepted: April 15, 2013
This is an Open Access article distributed under the terms of the Creative Commons Attribution Non-Commercial License (http://creativecommons.org/licenses/by-nc/3.0/) which permits unrestricted non-commercial use, distribution, and reproduction in any medium, provided the original work is properly cited. 
tions were $5.9 \pm 0.7 \mathrm{ng} / \mathrm{mL}$ in thin body and $26.9 \pm 3.9 \mathrm{ng} / \mathrm{mL}$ in obese body, meaning of results that leptin concentration has been high level by high level of body mass index (BMI) in obese. Moreover, Masuo et al. (2008) investigated leptin concentration in 129 white person to subjects that normal $\left(\mathrm{BMI}<22.0 \pm 1.9 \mathrm{~kg} / \mathrm{m}^{2}\right)$ was $4.48 \pm 3.01 \mathrm{ng} / \mathrm{mL}$ and over weight $\left(B M I>30.3 \pm 3.5 \mathrm{~kg} / \mathrm{m}^{2}\right)$ was $0.45 \pm 5.18 \mathrm{ng} / \mathrm{mL}$. These results that both groups according to body fat and BMI levels of leptin concentration changes can be said, that the amount of adipose tissue and leptin levels can be static correlation (Masuo et al., 2008). In other hands, Noland et al. (2001) reported that no change in leptin with fat loss might be due to training-induced increases in intense training. Fisher et al. (2001) administered a standardized meal to subjects and observed increases in leptin during $41 \mathrm{~min}$ of cycling at 50\% of the cycling intensity of $\mathrm{VO}_{2} \max$. This was followed by a reduction in leptin concentration during recovery that increased to control values after $2 \mathrm{~h}$. Weltman et al. (2000) reported that $30 \mathrm{~min}$ of exercise at, above, and below lactate threshold, an index of accelerated metabolism and exercise intensity, did not alter leptin concentration in young males during exercise or recovery compared with control values. But most previous studies of reported that leptin concentration closely related to body fat that insulin and growth hormone as well as obesity-related inflammatory factors have profound implications (Beck and Offenbacher, 2006; Kapoor et al., 2007).

In particular, the adipose tissue was promoting the production of pro-inflammatory cytokines related to obesity such as TNF- $\alpha$ and IL- 6 that obesity-related inflammatory factors causes anorexia and to regulate the metabolism of fat cells, leptin a function may play an important role (Marfella et al., 2004).

Thus, the presence of significant correlations in leptin, obesity-related inflammatory factors and body fat mass that leptin, and obesity-related inflammatory factors may reduce due to appetite control and weight loss after exercise. However, most previous studies of reported that the correlation between fat and obesity-related factors in the obese group. The backgrounds deficiency and necessary that direct effect of regular exercise relationship between fat and obesity-related factors in sturdy body man rather than being overweight or obese body. Therefore, the purpose of the present study was to find the change and correlation between related obesity factors and body composition according to regular exercise in sturdy body man.

\section{MATERIALS AND METHODS}

\section{Subjects and experimental design}

Subjects were recruited thirty-six sturdy men at twenty years old in ' $\mathrm{K}$ ' university students. The consent form for participation was signed and obtained from all participation. They were random divided into two groups, which was regular exercise group (REG, $\mathrm{n}=18$ ) and control group (CON, $\mathrm{n}=18)$. The subjects' characteristics before the study are presented in Table 1. By independent t-test, there was no significant difference among the subjects in age, height, weight, $\%$ fat and BMI.

\section{Measurement of related obesity factors}

Blood sample was obtained from all subjects at 8:00 am after an overnight fast before and after performing regular exercise, which was approximately $10 \mathrm{cc}$ of blood in the forearm veins by clinical pathologist. Leptin was assayed by means of a ${ }^{125}$ I RIA kit for human leptin (Linco Research Co., St. Charles, USA), TNF- $\alpha$, and IL- 6 was assayed by quantitative sandwich enzyme immunoassay technique.

\section{Measurement of body composition}

Body composition was estimated using the data obtained by way of bioeletrical impedance analysis (BIA; In-body 520, Seoul, Korea), which could measure height, weight, lean mass, body fat mass, \% fat, waist to hip ratio (WHR) and BMI (Thomson et al., 2009).

\section{Exercise program}

Exercise program consisted of warm-up (10 min), work-out (30-60 $\mathrm{min})$, and cool-down (10 $\mathrm{min}$ ) and the exercise group performed it for 8 weeks. In the work-out, aerobic exercise ( 6 days/ week; Mon-Sat) using a treadmill at $60 \%$ of heart rate reserve (HRR) was performed for $30 \mathrm{~min}$ and heart rates of exercise were continuously monitored using Polar ${ }^{\otimes}$ heart rate monitors. And then resistance exercise (3 days/week; Mon, Wed, Fri) was composed of nine different exercises for the large muscle in following order: leg press, chest press, lateral pull down, leg extension, leg

Table 1. Physical characteristic of subjects

\begin{tabular}{lccccc}
\hline Groups & Age $(\mathrm{yr})$ & Height $(\mathrm{cm})$ & Weight $(\mathrm{kg})$ & $\%$ fat & BMI $\left(\mathrm{kg} / \mathrm{m}^{2}\right)$ \\
\hline REG $(\mathrm{n}=18)$ & $23.83 \pm 1.62$ & $174.67 \pm 6.51$ & $76.87 \pm 8.00$ & $17.97 \pm 3.79$ & $25.25 \pm 1.79$ \\
CON $(\mathrm{n}=18)$ & $23.61 \pm 2.03$ & $173.11 \pm 4.87$ & $71.95 \pm 9.79$ & $20.64 \pm 6.79$ & $24.08 \pm 3.16$
\end{tabular}

All values are expressed as mean \pm standard deviation (SD).

$\mathrm{REG}$, regular exercise group; CON, control group. 
Table 2. Exercise program

\begin{tabular}{|c|c|c|c|}
\hline Items & Exercise & Intensity & Duration \\
\hline Warm-up & Slow walking/Stretching & Mild discomfort & $10 \mathrm{~min}$ \\
\hline \multirow[t]{5}{*}{ Work-out } & Walking (Treadmill) & HRR 60\% & $30 \mathrm{~min}$ \\
\hline & Resistance (arm, trunk, leg) & 1-2 wk: $1 \mathrm{RM} 50 \%$ & $15 \mathrm{reps} / 4$ sets \\
\hline & & 3-4 wk: 1RM 60\% & 12 reps/4sets \\
\hline & & 5-6 wk: 1RM 70\% & 10 reps/4sets \\
\hline & & 7-8 wk: 1RM 80\% & $8 \mathrm{reps} / 4 \mathrm{sets}$ \\
\hline Cool-down & Stretching & Mild discomfort & $10 \min$ \\
\hline
\end{tabular}

curl, abdomen curl, back extension, biceps curl and triceps curl. Exercise program was according to the principle recommended by ACSM manual (2003; 2006).

The subjects were instructed to follow a normal lifestyle maintaining daily habits and to refrain from alcohol and caffeine. The detail exercise programs are presented in Table 2 .

\section{Statistical analysis}

Statistical analysis was performed by using the SPSS (ver. 18.0; IBM Co., Armonk, NY, USA). All date were expressed as means \pm standard deviation (SD). Initially, the independent t-test was used to determine the significance among subgroups. Two-way ANOVA $(2 \times 2)$ with repeated measures on groups ( 2 levels) and time ( 2 levels) were used to determine the significance between subgroups. The correlation coefficient was determined and tested for significance using Pearson's regression (r). When interaction have appeared between subgroups that were used independent t-test and pair t-test. Delta differences $(\Delta \%)$ between different time points of each group were calculated using the following formula: $\Delta \%=$ (post-pre)/pre $\times 100$. The significance levels of $P<0.05$ were accepted for all comparisons.

\section{RESULTS}

\section{Change of obesity-related factors}

The difference and change of obesity-related factors after eight weeks in this study are presented in Table 3. Plasma leptin: After eight weeks, obesity-related factors was significantly decreased exercise group (from $3.41 \pm 1.80$ to $2.09 \pm 1.08 \mathrm{ng} / \mathrm{mL} ;-38.71 \%$ ) and control group (from $3.04 \pm 1.15$ to $2.31 \pm 1.33 \mathrm{ng} / \mathrm{mL} ;-24.02 \%$ ). On this, leptin was significantly difference between times $(P<$ $0.001)$, and interactions $(P<0.05)$. Independent t-test was no significant and pair t-test was significant difference in both groups $(P<0.001)$.

TNF- $\alpha$ : After eight weeks, obesity-related factors was decreased exercise group (from $1.74 \pm 0.86$ to $1.52 \pm 0.68 \mathrm{pg} / \mathrm{mL} ;-12.64 \%$ ) but, increased control group (from $1.50 \pm 0.64$ to $1.70 \pm 0.68 \mathrm{pg}$ / $\mathrm{mL} ;-13.33 \%)$. Here, TNF- $\alpha$ was no significantly difference.

IL-6: After eight weeks, obesity-related factors was decreased exercise group (from $1.32 \pm 1.80$ to $1.11 \pm 0.29 \mathrm{pg} / \mathrm{mL} ;-15.91 \%$ ) and control group (from $1.05 \pm 0.71$ to $1.00 \pm 0.59 \mathrm{pg} / \mathrm{mL}$; $-4.76 \%)$. In other words, IL-6 was no significantly difference.

\section{Change of body composition}

The difference and change of body composition after eight weeks in this study are presented in Table 3. Body weight: After eight weeks, significantly decreased exercise group (from $76.87 \pm$ 8.00 to $74.99 \pm 6.92 \mathrm{~kg} ;-2.45 \%$ ) but, increased control group (from $71.95 \pm 9.79$ to $72.12 \pm 9.23 \mathrm{~kg} ; 0.24 \%$ ). Namely, weight was significantly difference between times $(P<0.01)$, and interactions $(P<0.001)$. Independent t-test was no significant and pair t-test was significant difference in REG $(P<0.01)$.

Lean body mass: After eight weeks, significantly increased exercise group (from $54.99 \pm 10.4$ to $55.97 \pm 10.92 \mathrm{~kg} ; 1.78 \%$ ) but, decreased control group (from $49.79 \pm 8.41$ to $49.29 \pm 7.98 \mathrm{~kg}$; $-1.00 \%)$. Lean mass was significantly difference at interactions $(P<0.01)$. Independent $\mathrm{t}$-test was significant difference in post exercise $(P<0.05)$ and pair t-test was significant difference in REG $(P<0.01)$.

Body fat mass: After eight weeks, significantly decreased exercise group (from $13.82 \pm 3.18$ to $12.26 \pm 2.90 \mathrm{~kg}$; $-11.29 \%$ ) but, increased control group (from $15.31 \pm 7.04$ to $15.79 \pm 7.26 \mathrm{~kg}$; $3.14 \%)$. Namely fat mass was significantly difference between times $(P<0.01)$, and interactions $(P<0.001)$. Independent t-test was no significant and pair t-test was significant difference in REG $(P<0.001)$.

$\%$ fat: After eight weeks, significantly decreased exercise group (from $17.97 \pm 3.79$ to $15.97 \pm 3.36 \%$; $-11.13 \%$ ) but, increased control group (from $20.64 \pm 6.79$ to $20.97 \pm 7.58 \% ; 1.60 \%$ ). On this, \% fat was significantly difference among groups $(P<0.05)$, between times $(P<0.01)$, and interactions $(P<0.001)$. Independent t-test was significant difference in post exercise $(P<0.05)$ and pair t-test was significant difference in REG $(P<0.001)$.

Waist to bip ratio (WHR): After eight weeks, significantly decreased in exercise group (from $0.86 \pm 0.02$ to $0.84 \pm 3.360 .02 \%$; $-2.33 \%$ ) but, no changed in control group (from $0.86 \pm 0.03$ to $0.86 \pm 0.04 \% ; 0 \%)$. In other words, WHR was significantly difference among between times $(P<0.01)$, and interactions $(P<$ $0.001)$. Independent t-test was significant difference in post exercise $(P<0.05)$ and pair t-test was significant difference in REG $(P<0.001)$. 
Table 3. Changes of obesity-related factor and body composition after 8 weeks.

\begin{tabular}{|c|c|c|c|c|c|c|c|c|}
\hline \multirow{2}{*}{ Variable } & \multirow{2}{*}{ Groups } & \multirow{2}{*}{ Pre } & \multirow{2}{*}{ Post } & \multirow{2}{*}{$\Delta \%$} & \multirow{2}{*}{$\mathrm{t}$-values } & \multicolumn{3}{|c|}{ F-values in two-way repeated ANOVA } \\
\hline & & & & & & Groups & Times & Groups $\times$ Times \\
\hline \multirow[t]{3}{*}{ Leptin (ng/mL) } & REG & $3.41 \pm 1.80$ & $2.09 \pm 1.08$ & -38.71 & $0.000^{f}$ & 0.863 & $0.000^{c 1}$ & $0.041^{a)}$ \\
\hline & $\mathrm{CON}$ & $3.04 \pm 1.15$ & $2.31 \pm 1.33$ & -24.02 & $0.000^{\dagger}$ & & & \\
\hline & t-values & 0.468 & 0.592 & & & & & \\
\hline \multirow[t]{2}{*}{ TNF- $\alpha(p g / m L)$} & REG & $1.74 \pm 0.86$ & $1.52 \pm 0.68$ & -12.64 & & 0.845 & 0.964 & 0.236 \\
\hline & CON & $1.50 \pm 0.64$ & $1.70 \pm 0.68$ & 13.33 & & & & \\
\hline \multirow[t]{2}{*}{ IL-6 (pg/mL) } & REG & $1.32 \pm 1.80$ & $1.11 \pm 0.98$ & -15.91 & & 0.581 & 0.423 & 0.632 \\
\hline & CON & $1.05 \pm 0.71$ & $1.00 \pm 0.59$ & -4.76 & & & & \\
\hline \multirow[t]{3}{*}{ Weight (kg) } & REG & $76.87 \pm 8.00$ & $74.99 \pm 6.92$ & -2.45 & $0.002^{e)}$ & 0.179 & $0.006^{b)}$ & $0.001^{1)}$ \\
\hline & CON & $71.95 \pm 9.79$ & $72.12 \pm 9.23$ & 0.24 & 0.526 & & & \\
\hline & $\mathrm{t}$-values & 0.108 & 0.298 & & & & & \\
\hline \multirow[t]{3}{*}{ Lean mass (kg) } & REG & $54.99 \pm 10.46$ & $55.97 \pm 10.92$ & 1.78 & $0.009^{e)}$ & 0.069 & 0.363 & $0.007^{b)}$ \\
\hline & CON & $49.79 \pm 8.41$ & $49.29 \pm 7.98$ & -1.00 & 0.209 & & & \\
\hline & t-values & 0.110 & $0.044^{g)}$ & & & & & \\
\hline \multirow[t]{3}{*}{ fat mass (kg) } & REG & $13.82 \pm 3.18$ & $12.26 \pm 2.90$ & -11.29 & $0.000^{\dagger}$ & 0.177 & $0.010^{b)}$ & $0.000^{c l}$ \\
\hline & CON & $15.31 \pm 7.04$ & $15.79 \pm 7.26$ & 3.14 & 0.082 & & & \\
\hline & t-values & 0.421 & 0.063 & & & & & \\
\hline \multirow[t]{3}{*}{$\%$ fat $(\%)$} & REG & $17.97 \pm 3.79$ & $15.97 \pm 3.36$ & -11.13 & $0.000^{\dagger)}$ & $0.049^{a)}$ & $0.002^{b)}$ & $0.000^{c l}$ \\
\hline & CON & $20.64 \pm 6.79$ & $20.97 \pm 7.58$ & 1.60 & 0.413 & & & \\
\hline & $\mathrm{t}$-values & 0.154 & $0.015^{9 l}$ & & & & & \\
\hline \multirow[t]{3}{*}{ WHR (\%) } & REG & $0.86 \pm 0.02$ & $0.84 \pm 0.02$ & -2.33 & $0.000^{\dagger)}$ & 1.763 & $13.307^{\mathrm{bl}}$ & $14.871^{c)}$ \\
\hline & CON & $0.86 \pm 0.03$ & $0.86 \pm 0.04$ & 0.00 & 0.871 & & & \\
\hline & t-values & 0.806 & $0.037^{9 l}$ & & & & & \\
\hline \multirow[t]{3}{*}{$\mathrm{BMI}\left(\mathrm{kg} / \mathrm{m}^{2}\right)$} & REG & $25.25 \pm 1.79$ & $24.63 \pm 1.24$ & -2.46 & $0.000^{f}$ & 0.306 & $0.006^{b l}$ & $0.001^{c)}$ \\
\hline & CON & $24.08 \pm 3.16$ & $24.14 \pm 2.97$ & 0.25 & 0.525 & & & \\
\hline & $\mathrm{t}$-values & 0.179 & 0.518 & & & & & \\
\hline
\end{tabular}

All values are expressed as mean \pm SD. ${ }^{a, b, b, c l}$ Represent the significant effect in two-way repeated ANOVA $P<0.05,0.01$, and 0.001 . el, fif Represent the significant effect in paired t-test $P<0.05,0.01$, and 0.001 . ${ }^{9}$ Represents the significant effect in independent t-test $P<0.05$.

No marking is not significant. REG, regular exercise group; CON, control group; WHR, waist to hip ratio; BMI, body mass index.

Body mass index (BMI): After eight weeks, significantly decreased in exercise group (from $25.25 \pm 1.79$ to $24.63 \pm 1.24 \mathrm{~kg}$ / $\mathrm{m}^{2} ;-2.46 \%$ ) but, increased in control group (from $24.08 \pm 3.16$ to $\left.24.14 \pm 2.97 \mathrm{~kg} / \mathrm{m}^{2} ; 0.25 \%\right)$. Namely, BMI was significantly difference between times $(P<0.01)$, and interactions $(P<0.001)$. Independent t-test was no significant and pair t-test was significant difference in REG $(P<0.001)$.

\section{Correlation of related obesity factors and body composition}

The correlation of obesity-related factors and body composition after eight weeks on regular exercise in this study are presented in Table 4. Eight weeks on regular exercise, TNF- $\alpha$ in obesity-related factors was positively correlated with weight $(\mathrm{r}=0.392, P<0.05)$, lean mass $(\mathrm{r}=0.359, P<0.05)$, and fat mass $(\mathrm{r}=0.355, P<0.05)$.

\section{DISCUSSION}

The purpose of this study was to find the change and correlation between related obesity factors and body composition according to regular exercise in 36 sturdy body men. Regular exercise can improve blood lipids and body composition, reduces the risk of chronic diseases such as coronary artery disease, moreover it improve the quality of life (Thompson et al., 2003). However, physical inactivity and excess nutrition increased the amount of adipose tissue, which eventually leads to being overweight or obese, adipose tissue caused of synthesis and secretion of obesity-related factors such as leptin, TNF- $\alpha$, and IL-6 (Fruhbeck et al., 2001). Leptin serum level correlates with fat stores and reacts according to changes in energy balance (Zurowski et al., 2001).

Obesity-related inflammation such as TNF- $\alpha$ and IL-6 is secreted from serum total cholesterol of adipose tissue and control 
Table 4. Correlation of obesity-related factors and body composition after 8 weeks on regular exercise

\begin{tabular}{llllllll}
\hline Variable & & $\begin{array}{c}\text { Weight } \\
(\mathrm{kg})\end{array}$ & $\begin{array}{c}\text { Lean } \\
\text { mass } \\
(\mathrm{kg})\end{array}$ & $\begin{array}{c}\text { Fat } \\
\text { mass } \\
(\mathrm{kg})\end{array}$ & $\begin{array}{c}\text { \% fat } \\
(\%)\end{array}$ & $\begin{array}{c}\text { WHR } \\
\left(\mathrm{kg} / \mathrm{m}^{2}\right)\end{array}$ \\
\hline Pre & Leptin $(\mathrm{ng} / \mathrm{mL})$ & 0.312 & 0.208 & 0.051 & -0.058 & -0.050 & 0.310 \\
exercise & TNF- $\alpha(\mathrm{pg} / \mathrm{mL})$ & -0.206 & 0.329 & -0.148 & -0.109 & -0.169 & -0.166 \\
& $\mathrm{IL}-6(\mathrm{pg} / \mathrm{mL})$ & -0.042 & 0.039 & -0.147 & -0.161 & -0.113 & 0.018 \\
Post & Leptin $(\mathrm{ng} / \mathrm{mL})$ & 0.327 & 0.218 & -0.014 & -0.132 & -0.202 & -0.306 \\
exercise & TNF- $\alpha(\mathrm{pg} / \mathrm{mL})$ & $0.392^{\text {a) }}$ & $0.359^{\text {a) }}$ & $0.355^{\mathrm{a}}$ & 0.221 & 0.312 & 0.327 \\
& $\mathrm{IL}-6(\mathrm{pg} / \mathrm{mL})$ & 0.075 & 0.099 & -0.112 & -0.152 & -0.158 & -0.019 \\
\hline
\end{tabular}

${ }^{a}$ Represent the significant effect in two-way repeated ANOVA $P<0.05,0.01$, and 0.001 .

No marking is not significant. WHR, waist to hip ratio; BMI, body mass index.

the metabolism of fat, positive relationship BMI and body fat (Streetz et al., 2001). Moreover, these obesity-related factors were higher in subcutaneous fat tissue and visceral fat tissue of obese than lean people (Dusserre et al., 2000). But most many previous studies reported that leptin, TNF- $\alpha$ and IL-6 decreased according to fat loss due to regular exercise in obesity body (Canavan et al., 2005; George, 2003). Gmez-Merino et al. (2002) compared regular exercise group and non exercise group that obese subject, which induced an energy deficiency, reduced serum leptin to exercise group. The authors concluded that loss of body fat to the effect of exercise might increase in reduction of the leptin hormone in regular exercise, according to verified improvements. Halle et al. (1999) studied obese males and reported that 1 month of cycling exercise in reduced body weight and leptin concentration. Monzillo et al. (2003) reported that weight reduction in obese individuals on moderate physical activity was associated with a significant decrease in leptin, TNF- $\alpha$ and IL-6.

These studies suggest an important link between obesity-related inflammation (leptin, TNF- $\alpha$, IL-6) and regular exercise in overweight or obese. However, a little study have subject in sturdy body men. Therefore, the aim of our study was to find the change between obesity-related inflammation and body composition according to regular exercise in sturdy body men, which not being overweight or obese body.

The present study showed that an 8-week regular exercise significantly decreased leptin level in the both control and regular exercise groups, and it reduced in regular exercise group than that of control group. Our findings supports previous studies, Nindl et al. (2002) studied the effects of aerobic training and resistance on leptin in healthy men. The result, between the control and exercise groups were significantly difference and both groups decreased. Moreover, Elias et al. (2000) compared a treadmill exercise to a control that reported a decline in leptin concentrations in healthy males after treadmill exercise. The authors suggested that the decline may be associated with elevated production of non-esterfied fatty acids.

In addition, although no significant, an 8-week regular exercise reduced TNF- $\alpha$ and IL- 6 levels compared to before the regular exercise, and in compared to control and exercise groups, an 8-week regular exercise suppressed TNF- $\alpha$ and IL- 6 levels than those of control group. These results indicated that regular exercise changed a decrease obesity related hormone of leptin level, and reduced the inflammatory-related factors of TNF- $\alpha$ and IL-6. In generally, leptin and IL-6, due to excessive fat accumulation, is keeps going maintain or increased of adipose tissue to problem sensitivity and resistance of leptin in obese body. But, we thought that the subject of this study, because of sturdy body men were sensitivity and resistance to normal function as appears normal function of appetite suppressant, leptin and IL-6 was decreased in both sturdy body men. Also, we would suggest that effect was reduced as with other previous studies in circadian rhythm, as well as body fat and blood concentration in both groups.

In this study, after eight weeks, weight, fat mass, \% fat, WHR as well as BMI was significantly decrease exercise group but increased control group. On the other hand, lean mass was significantly increased exercise group but, decreased control group. Additional date derived from correlation of obesity-related factors and body composition was appear that TNF- $\alpha$, obesity-related factors, was positively correlated with weight, lean mass, and fat mass in regular exercise. Nicklas et al. (2005) reported that TNF- $\alpha$ release was appeared the higher to affect of adipose mass and elevated in people with a higher fat mass. Kerm et al. (1995) reported that TNF- $\alpha$ has multiple actions in adipose tissue, which include a decrease in weight loss and an increase in lean mass.

The results of this study are appeared by these subjects and the short period of time. Further studies will be needed a statistical analysis method through increased number of subjects, a variety of exercise intensity and duration of exercise, as well as $24 \mathrm{~h}$ cycle changes and the physiological mechanisms of blood concentration.

\section{CONFLICT OF INTEREST}

No potential conflict of interest relevant to this article was reported. 


\section{REFERENCES}

Ahima RS, Flier JS. Adipose tissue as an endocrine organ. Trends Endocrinol Metab 2000;11:327-331.

American College of Sports Medicine. ACSM's guidelines for exercise testing and prescription. 7th Philadelphia: Lippincott. William \& Wilkins; 2006.

American College of Sports Medicine. Exercise prescription; A case study approach to the ACSM guidelines. Himan Kinetics; 2003.

Beck JD, Offenbacher S. Systemic effect of periodontitis: epidemiology of periodontal disease and cardiovascular disease. J Periodontol 2006;76: 2089-2100.

Canavan B, Salem RO, Schurgin S, Koutkia P, Lipinska I, Laposata M, Grinspoon S. Effects of physiological leptin administration on markers of inflammation, platelet activation, and platelet aggregation during caloric deprivation. J Clin Endocrinol Metab 2005;90:5779-5785.

Dusserre E, Moulin P, Vidal H. Differences in mRNA expression of the proteins secreted by the adipocytes in human subcutaneous and visceral adipose tissue. Biochim Biophys Acta 2000;1500:88-96.

Elias AN, Pandian MR, Wang L, Suarez E, James N, Wilson AF. Leptin and IGF-I levels in unconditioned male volunteers after short-term exercise. Psychoneuroendocrinology 2000;25:453-461.

Enriori PJ, Evans AE, Sinnayah P, Cowley MA. Leptin resistance and obesity. Obesity 2006;14:254-258.

Fisher JS, Van-Pelt RE, Zinder O, Landt M, Kohrt WM. Acute exercise effect on postabsorptive serum leptin. J Appl Physiol 2001;91:680-686.

Fruhbeck G, Gomez-Ambrosi J, Muruzable FJ. The adipocyte: a model for integration of endocrine and matabolic signaling in energy metabolism regulation. Am J Physiol Endocrinol Metab 2001;280: 827-857.

George W. Adiponectin: a regulator of energy homeostasis. Nutr Rev 2003;61:290-292.

Gomez-Merino D, Chennaoui M, Drogou C, Bonneau D, Guezennec CY. Decrease in serum leptin after prolonged physical activity in men. Med Sci Sports Exerc 2002;34:1594-1599.

Halle M, Berg A, Garwers U, Grathwohl D, Knisel W, Kuel J. Concurrent reductions of serum leptin and lipids during weight loss in obese males with type II diabetes. Am J Physiol Endocrinol Metab, 1999;277: 2777-2782

Houmard JA, Cox JH, MacLean PS, Barakat HA. Effect of short-term exercise training on leptin and insulin action. Metabolism 2000;49:858861.

Kapoor D, Clarke S, Stanworth R, Channer KS, Jones TH. The effect of testosterone replacement therapy on adipocytokines and C-reactive protein in hypogonadal men with type 2 diabetes. Eur J Endocrinol 2007;156: 595-602.
Kerm PA, Saghizadeh M, Ong JM, Bosch RJ, Deem R, Simsolo RB. The expression of tumor necrosis factor in human adipose tissue regulation by obesity, weight loss, and relationship to lipoprotein lipase. Clin Res 1995;95:2111-2119.

Kim YS, Lee SY, Kim YO. Nutrition education and aerobic exercise program on weight control program of middle age abdominal obese woman. Korean Journal of human ecology 2002;9:65-73.

Ko JS. Impact of dietary habits and academic stress on obesity in elementary schoolers. Graduate School of Myong Ji University; 2007.

Kraemer RR, Chu H, Castracane VD. Leptin and Exercise. Aust J Exp Biol Med Sci 2002;227:701-708.

Marfella R, Esposito K, Siniscalchi M, Cacciapuoti F, Giugliano F, Labriola D, Ciotola M, Di-Palo C, Misso L, Giugliano D. Effect of weight loss on cardiac synchronization and proinflammatory cytokines in premenopausal obese women. Diabetes Care 2004;27:47-52.

Masuo K, Straznicky NE, Lambert GW, Katsuya T, Sugimoto K, Rakugi H, Socratous F, Hastings J, Lambert EA, Ogihara T, Esler MD. Leptin-receptor polymorphisms relate to obesity through blunted leptin-mediated sympathetic nerve activation in a caucasian male poulation. Hypertens Res 2008;31:1093-1100.

Monzillo LU, Hamdy O, Horton ES, Ledbury S, Mullooly C, Jarema C, Porter S, Ovalle K, Moussa A, Mantzoros CS. Effect of lifestyle modification on adipokine levels in obese subjects with insulin resistance. Obes Res 2003;11:1048-1054.

Nicklas BJ, You T, Pahor M. Behavioural treatments for chronic systemic inflammation: effect of dietary weight loss and exercise training. CMAJ 2005;172:1199-1209.

Nindl BC, Kraemer WJ, Arciero PJ, Samatallee N, Leone CD, Mayo MF, Hafeman DL. Leptin concentrations experience a delayed reduction after resistance exercise in men. Med Sci Sports Exerc 2002;34:608-613.

Noland RC, Baker JA, Boudreau SR, Kobe RW, Tanner CJ, Hickner RC, Mccammon MR, Houmard JA. Effect of intense training on plasma leptin in male \& female swimmers. Med Sci Sports Exerc 2001;33:227231.

Sartorio A, Agosti F, Resnik M, Lafortuna CL. Effect of a 3-week integrated body weight reduction program on leptin levels and body composition in severe obese subjects. J Endocrinol Invest 2003;26:250-256.

Silha JV, Krsek M, Skrha JV, Sucharda P, Nyomba BL, Murphy LJ. Plasma resistin, adiponectin and leptin levels in lean and obese subjects: correlations with insulin resistance. Eur J Endocrinol 2003;149:331-335.

Streetz KL, Wustefeld T, Klein C, Manns MP, Trautwein C. Mediators of inflammation and acute phase response in the liver. Mol Biol Cell 2001; 47:661-673.

Thompson PD, Buchner D, Pina IL, Balady GJ, Williams MA, Marcus BH, Berra K, Blair SN, Costa F, Franklin B, Fletcher GF, Gordon NF, Pate 
RR, Rodriguez BL, Yancey AK, Wenger NK. Exercise and physical activity in the prevention and treatment of atherosclerotic cardiovascular disease: a statement from the Council on Clinical Cardiology (Subcommittee on Exercise, Rehabilitation, and Prevention) and the Council on Nutrition, Physical Activity, and Metabolism (Subcommittee on Physical Activity). Circulation 2003;24:3109-3116.

Thomson JS, Watson PE, Rowlands DS. Effect of nine weeks of beta-hydroxy-beta methylbutyrate supplementation on strenght and body composition in resistance training men. J Strength Cond Res 2009;23: 827-835.
Weltman A, Widemman L, Considien RV, Fryburg DA, Gutgesell ME, Hartman ML, Veldhuis JD. Intensityof acute exercise does not affect serum leptin concentrations in young men. Med Sci Sports Exerc 2000; 32:1556-1561.

Ziccardi P, Nappo F, Giugliano G, Esposito K, Marfella R, Cioffi M, D’Andrea F, Molinari AM, Giugliano D. Reduction of inflammatory cytokine concentrations and improvement of endothelial function in obese women after weight loss over one year. Circulation 2002;105:804-809.

Zurowski D, Koprowska B, Thor PJ. The role of leptin in metabolic regulation. Folia Med Cracov 2001;42:83-93. 